\title{
PENINGKATAN HASIL BELAJAR BAHASA INDONESIA MELALUI METODE ROLE PLAYING PADA SISWA SEKOLAH DASAR
}

\author{
Fauzatul Ma'rufah Rohmanurmeta
}

Surel: ayuputri368@yahoo.com

Naskah diterima: 21 September 2016.; direvisi: 8 Maret 2017; disetujui: 21 April 2017

\begin{abstract}
The purpose of this study was to determine the application of the method of role playing, improved learning outcomes, and the advantages and disadvantages of the methods of role playing in elementary school. This research use desciptive qualitative approach. Subjects in the study third grade students numbering nine people. This type of research is classroom action research with data collection through testing, observation and documentation. These data analysis techniques using data analysis with interactive models, and in the activities of analysis and data collection activities using two cycles of the first cycle and the second cycle. The results showed an increase learning outcomes Indonesian teaching methods for role playing in a drama about the beauty of nature with the provisions of $\geq 70$ value as much as $80 \%$ of students, in cooperation with the provisions $\geq 75$ students as much as $80 \%$ and motivated students with the provisions of $\geq 75$ value as much as $80 \%$. Therefore, it can be seen the advantages of this model is to make learning more fun, can improve learning outcomes Indonesian, cultivate the potential of students, improve student collaboration. While the drawbacks is that it takes a long time and needed a place large enough.
\end{abstract}

Keywords: learning outcomes, indonesian language, role playing method

\begin{abstract}
ABSTRAK
Tujuan penelitian ini adalah mengetahui penerapan metode role playing, peningkatan hasil belajar, dan kelebihan serta kekurangan metode role playing di kelas SD. Penelitian ini menggunakan pendekatan deskriptif kualitatif. Subyek yang diteliti adalah siswa kelas III yang berjumlah 9 orang. Jenis penelitian yang digunakan adalah penelitian tindakan kelas dengan teknik pengumpulan data melalui tes, observasi, dan dokumentasi. Teknik analisis data ini menggunakan analisis data dengan model interaktif, dan dalam kegiatan analisis serta kegiatan pengumpulan data menggunakan 2 siklus yaitu siklus I dan siklus II. Hasil penelitian menunjukkan adanya peningkatan hasil pembelajaran Bahasa Indonesia menggunakan metode pembelajaran role playing dalam drama tentang keindahan alam dengan ketentuan nilai $\geq 70$ sebanyak $80 \%$ siswa, kerjasama siswa dengan ketentuan $\geq 75$ sebanyak $80 \%$ dan motivasi siswa dengan ketentuan nilai $\geq 75$ sebanyak $80 \%$. Sehingga dapat dilihat kelebihan model ini adalah membuat pembelajaran lebih menyenangkan, dapat meningkatkan hasil pembelajaran bahasa Indonesia, menumbuhkan potensi siswa, meningkatkan kerjasama siswa. Sedangkan kekurangannya adalah memerlukan waktu yang lama dan membutuhkan tempat yang cukup luas.
\end{abstract}

Kata kunci: hasil belajar, bahasa Indonesia, metode role playing 


\section{PENDAHULUAN}

Bahasa Indonesia merupakan suatu mata pelajaran yang terdapat di dalam kurikulum pendidikan Indonesia, mata pelajaran bahasa Indonesia diberikan disetiap jenjang pendidikan mulai dari pendidikan dasar, bahkan sampai tingkat pendidikan perguruan tinggi masih terdapat pendidikan Bahasa Indonesia. Harapan utama dari adanya pendidikan Bahasa Indonesia adalah membimbing siswa agar dapat menggunakan Bahasa Indonesia sebagai sarana komunikasi dengan baik dan benar. Pembelajaran Bahasa Indonesia berdasarkan kurikulum saat ini berbasis terhadap perkembangan karakter dan keterampilan, namun pengimplementasian pembelajaran Bahasa Indonesia di sekolah saat ini masih banyak yang berbasis teori atau kognisi saja. Ada beberapa permasalahan di dalam kelas karena penerapan proses pendidikan Bahasa Indonesia belum optimal. Permasalahan tersebut yaitu hasil belajar Bahasa Indonesia masih cenderung rendah atau di bawah KKM. Hal tersebut tergambar pada nilai yang diperoleh, yaitu 67. Sementara itu, KKM pelajaran Bahasa Indonesia adalah 70 sehingga hasil belajar tersebut dinyatakan rendah. Interaksi di dalam pelajaran Bahasa Indonesia masih cenderung kurang, hal tersebut menjadikan perkembangan afektif dan psikomotor siswa menjadi rendah. Kurangnya motivasi belajar dalam mempelajari mata pelajaran Bahasa Indonesia karena kurangnya inovasi dalam pembelajaran Bahasa Indonesia. Aktifitas pembelajaran Bahasa Indonesia di dalam kelas cenderung bersifat behavioristik yaitu hanya terbatas pada stimulus dan respon saja, proses belajar di dalam kelas belum menerapkan proses belajar secara bermakna.

Penyebab timbulanya permasalahan di kelas terkait pelajaran Bahasa Indonesia diantaranya dikarenakan, materi pelajaran Bahasa Indonesia kurang melekat dalam pemahaman siswa, hal tersebut dikarenakan siswa mempelajari Bahasa Indonesia dengan menghafal konsep, akan lebih bermakna apabila Bahasa Indonesia diajarkan secara bermakna di dalam kelas. Aktifitas yang terbangun di dalam pelajaran Bahasa Indonesia kurang aktif disebabkan kurang adanya kesempatan bagi siswa untuk menampilkan kemampuanya berbahasa melalui pembelajaran bahasa yang bermakna.

Penerapan metode pembelajaran role playing dalam mata pelajaran Bahasa Indonesia adalah upaya untuk mengatasi permasalahan dalam pembelajaran Bahasa Indonesia, serta dapat membuat siswa untuk belajar secara bermakna, sehingga dapat meningkatkan hasil belajar Bahasa Indonesia pada siswa.

Penggunaan metode role playing dinilai dapat meningkatkan hasil belajar Bahasa Indonesia bagi siswa. Hal tersebut dikarenakan dengan belajar secara bermakna, pemahaman siswa terhadap materi akan lebih optimal sehingga hasil belajar siswa pun akan meningkat. Metode ini dianggap sejalan dengan tujuan kurikulum yang diharapkan dapat meningkatkan karakter siswa melalui proses belajar secara bermakna.

\section{Pembelajaran Bahasa Indonesia}

Menurut Pamungkas (2012: 11) menjelaskan bahwa Bahasa Indonesia merupakan bahasa yang dipergunakan sebagai pengantar dalam dunia pendidikan. Bahasa Indonesia adalah alat komunikasi yang dipergunakan oleh masyarakat Indonesia untuk keperluan sehari-hari, misalnya belajar, bekerjasama, dan berinteraksi. Belajar bahasa Indonesia sebagai suatu perubah perilaku yang relatif permanen dan merupakan hasil pelatihan berbahasa yang mendapat penguatan. Belajar bahasa merupakan usaha yang panjang dan kompleks seluruh jiwa raga yang terlibat ketika mempelajari bahasa. Keterlibatan menyeluruh, kepedulian yang terus-menerus, baik fisik, intelektual, emosional, sangat diperlukan untuk dapat menguasai bahasa.

Kegiatan pembelajaran Bahasa Indonesia akan berhasil apabila guru me- 
nyesuaikan pembelajaran dengan kemampuan siswa. Penyesuaian tersebut harus dirancang secara terpadu dengan tujuan pembelajaran Bahasa Indonesia. Misalnya: tujuan utama pembelajaran bahasa umumnya adalah mempersiapkan siswa untuk melakukan interksi yang bermakna dengan bahasa alamiah. Supaya interaksi dapat bermakna bagi siswa perlu didesain secara tepat rencana pembelajaran Bahasa Indonesia diarahkan pada siswa sebagai subyek belajar.

\section{Metode Pembelajaran Bahasa Indonesia}

Menurut Yunus (2012: 18-19) Metode merupakan rencana keseluruhan bagi penyajian bahan bahasa secara rapi dan tertib, yang tidak ada bagian-bagiannya yang berkontradiksi dan kesemuanya itu didasarkan pada pendekatan terpilih. Metode adalah tingkat yang menerapkan teori-teori pada tingkat pendekatan. Dalam tingkat ini dilakukan keterampilanketerampilan khusus yang akan dibelajarkan, materi yang harus disajikan di sistematika urutannya.

Heru (2015: 69) berpendapat bahwa metode berkaitan dengan cara-cara yang akan digunakan guru dalam menyampaikan materi pembelajaran. Sebelum melaksanakan pembelajaran, guru perlu menentukan metode yang akan digunakannya. Tentu saja, perencanaan metode pembelajaran yang akan digunakan didasarkan pada karakteristik materi, siswa, dan tujuannya. Untuk itu, tugas guru adalah paham metode serta karakteristik materi, siswa, dan tujuannya. Dengan memahami kedua aspek tersebut, maka guru pun bisa menentukan metode yang tepat untuk menyampaikan materi dalam pembelajaran.

Dari uraian di atas dapat disimpulkan bahwa dalam pembelajaran kreatif, pemilihan metode bersifat komunikatif, kombinatif, dan apersiatif. Komunikatif berarti bahwa metode apa pun yang digunakan haruslah metode yang bisa menjalin komunikasi yang baik antara guru dengan siswa. Untuk mewujudkan hubungan komunikasi yang baik, maka penggunaan metode idealnya bersifat kombinatif. Artinya, guru tidak saja menggunakan satu metode, tetapi banyak metode dalam satu pembelajaran yang dikombinasikan menjadi satu secara simultan. Dengan kombinasi metode ini, maka guru dalam mengajar berkecenderungan apresiatif karena seluruh potensi kecerdasan siswa bisa diakomodasikan melalui pembelajaran yang tepat.

\section{Metode Role Playing}

Metode pembelajaran role playing dirasa efektif apabila digunakan untuk meningkatkan keterampilan berbicara siswa karena dalam metode ini siswa melakukan kegiatan untuk bermain peran sesuai dengan bagiannya masing-masing. Menurut Saefudin \& Bediarti (2014: 133) "Role playing atau bermain peran artinya mendramatisasi cara bertingkah laku dalam hubungan sosial dengan peserta didik diikutsertakan dalam memainkan peran dalam dramatisasi tersebut". Peserta didik bertingkah laku seolah-olah menjadi sosok yangsama persis seperti yang diperankan sehingga masuk dalam kondisi yang diperankan seperti yang terjadi dalam kehidupan sosial atau kehidupan seharihari peserta didik. Peserta didik seperti sedang memainkan sebuah drama dalam pementasan.

Model role playing ini digunakan untuk mencapai beberapa bentuk tujuan pembelajaran baik secara instruksional maupun pengiring. Uno (2014: 26) mengungkapkan "Bermain peran sebagai suatu model pembelajaran bertujuan untuk membantu siswa menemukan makna makna diri (jati diri) di dunia sosial dan memecahkan dilema dengan bantuan kelompok". Artinya, melalui bermain peran siswa belajar menggunakan konsep peran, menyadari adanya peran-peran yang berbeda dan memikirkan perilaku dirinya dan perilaku orang lain. Sehingga ketika siswa memainkan suatu peranan orang lain ke dalam dirinya, siswa menjadi mengerti 
tentang tokoh yang diperankan siswa tersebut menjadi dirinya.

Keberhasilan model pembelajaran melalui bermain peran tergantung pada kualitas permainan peran yang diikuti dengan analisis terhadapnya. Disamping itu, tergantung pula pada persepsi siswa tentang peran yang dimainkan terhadap situasi yang nyata. Uno (2014: 26-28) menyebutkan bahwa prosedur bermain peran terdiri atas sembilan langkah, yaitu (1) pemanasan (warming up), (2) memilih partisipan, (3) menyiapkan pengamat (observer), (4) menata panggung, (5) memainkan peran (manggung), (6) diskusi dan evaluasi, (7) memainkan peran ulang (manggung ulang), (8) diskusi dan evaluasi kedua, dan (9) berbagai pengalaman dan kesimpulan.

\section{METODE PENELITIAN}

Penelitian ini menggunakan pendekatan Kualitatif melalui metode Penelitian Tindakan Kelas (PTK). Pendekatan kualitatif merupakan prosedur penelitin yang menghasilkan data deskriptif berupa kata-kata tertulis atau lisan dari orangorang dan prilaku yang diamati. Jenis penelitian ini merupakan Penelitian Tindakan Kelas (Classrom Action Research) yaitu usaha peningkatan kemampuan siswa yang dilakukan melalui kerja kolaborasi antara kepala sekolah, guru kelas dan peneliti di lingkungan. Penelitian ini dimaksudkan untuk memberi informasi bagaimana tindakan yang tepat untuk meningkatkan hasil belajar siswa melalui metode role playing. Teknik pengumpulan data yang digunakan adaah tes, dokumentasi, dan wawancara. Teknik analisis data pada penelitian ini adalah analisis data kualitatif. Dalam jenis kegiatan analisis dan kegiatan penggumpulan data itu sendiri merupakan siklus dan interaktif. Teknik analisis data dilakukan dengan menggunakan teknik analisis data model interaktif. Dalam analisis ini telah dikemukakan tiga hal utama, yaitu reduksi data, penyajian data, dan penarikan kesimpulan atau verifikasi.

\section{HASIL PENELITIAN DAN PEM- BAHASAN}

\section{Hasil Penelitian}

Hasil penelitian ini meliputi data awal siswa terkait hasil belajar Bahasa Indonesia, data hasil penerapan siklus satu dan data hasil penerapan siklus dua yang berorintasi pada hasil belajar Bahasa Indonesia siswa kelas III, data motivasi siswa dan data kerjasama siswa.

1. Data Awal Siswa.

Dari hasil observasi data awal siswa dapat dijelaskan bahwa siswa yang mengalami ketuntasan belajar sebanyak 6 anak dari 10 anak (60\%). Penetapan ketuntasan belajar berdasarkan indikator keberhasilan, yaitu mencapai nilai 70,0 sebagai batas ketuntasan belajar minimum.

2. Data Siklus 1

a. Observasi

Kegiatan observasi digunakan untuk memperoleh data motivasi dan kerjasama siswa dalam pelajaran.

Motivasi.

Penggunaan metode pembelajaran role playing untuk meningkatkan hasil belajar siswa kelas III pada siklus I mendapatkan respons yang baik dari siswa. Pada saat pembelajaran, siswa cukup banyak yang termotivasi dalam pembelajaran.

Kerjasama.

Hasil observasi penggunaan metode pembelajaran role playing untuk meningkatkan hasil belajar siswa pada siklus I sudah berjalan dengan baik. Tiap kelompok berani maju kedepan dan memerankan drama dengan baik dan kompak secara bergantian dan kelompok lain mengomentari isi dari drama yang diperankan dengan baik dan antusias.

b. Wawancara

Peneliti melakukan wawancara pada semua siswa. Teknik dari 
pengumpulan data melalui wawancara ialah dengan angket kuesioner. Hal tersebut bertujuan untuk mengetahui aktivitas siswa dalam pembelajaran, apresiasi pembelajaran, interaksi dalam pembelajaran, dan pengembangan setelah menerima pembelajaran.

c. Tes

Terdapat hasil belajar Bahasa Indonesia menggunakan metode pembelajaran role playing untuk meningkatkan hasil belajar. Hasil test tersebut ialah hasil secara individu

Indikator keberhasilan tindakan pada siklus 1 adalah sebagai berikut.

\begin{tabular}{lll}
\hline Aspek & Ketercapaian & Indikator \\
\hline Test & $70 \%$ & $80 \% \geq 70$ \\
\hline Motivasi & $70 \%$ & $80 \% \geq 70$ \\
\hline Kerjasama & $70 \%$ & $80 \% \geq 70$ \\
\hline
\end{tabular}

Dari paparan tabel di atas, dapat dijelaskan bahwa kurang dari $80 \%$ hasil belajar siswa meningkat dengan metode pembelajaran role pkaying. Pencapaian hanya $70 \%$ dari 10 siswa yaitu 7 siswa yang telah mencapai ketuntasan belajar Bahasa Indonesia dan 3 siswa belum tuntas. Pada observasi motivasi belajar dan kerjasama, kurang dari $80 \%$ siswa dapat memperhatikan pelajaran dengan baik dan antusias dalam pembelajaran serta bekerjasama secara kompak untuk menampilkan peran di depan kelas.

\section{Data Siklus 2}

a. Observasi

Kegiatan observasi digunakan untuk memperoleh data motivasi dan kerjasama siswa dalam pelajaran.

Motivasi.

Penggunaan metode role playing untuk meningkatkan hasil belajar siswa kelas III pada siklus II mendapatkan respons yang sangat baik dari siswa. Pada saat pembelajaran, siswa cukup banyak yang termotivasi dalam pembelajaran. Kerjasama.

Hasil observasi penggunaan metode role playing untuk meningkatkan hasil belajar siswa kelas III pada siklus II berjalan dengan lebih baik. Pada saat pembelajaran, utamanya pada diskusi kelompok dan berpendapat mengenai isi peran kelompok lain, siswa dapat menyampaikan pendapat dengan lebih dari 3 kali dalam berdiskusi dan memberikan contoh peran yang menurutnya baik dalam ekspresi memerankan drama.

b. Wawancara

Peneliti melakukan wawancara pada semua siswa kelas III. Teknik dari pengumpulan data melalui wawancara ialah dengan angket kuesioner. Hal tersebut bertujuan untuk mengetahui aktivitas siswa dalam pembelajaran, apresiasi pembelajaran, interaksi dalam pembelajaran, dan pengembangan setelah menerima pembelajaran.

c. Tes.

Terdapat hasil belajar Bahasa Indonesia menggunakan metode pembelajaran role playing untuk meningkatkan hasil belajar Bahasa Indonesia. Hasil test tersebut ialah hasil secara individu

Indikator keberhasilan tindakan pada siklus 1 adalah sebagai berikut.

\begin{tabular}{lll}
\hline Aspek & Ketercapaian & Indikator \\
\hline Test & $80 \%$ & $80 \% \geq 70$ \\
\hline Keaktifan & $85 \%$ & $80 \% \geq 70$ \\
\hline Keberanian & $90 \%$ & $80 \% \geq 70$ \\
\hline
\end{tabular}

Dari paparan tabel diatas, dapat dijelaskan bahwa sudah lebih atau sama dengan $80 \%$ hasil belajar siswa meningkat menggunakan teks drama dengan menerapkan metode role 
playing. Selain hasil tes yang mengalami peningkatan, kegiatan berdiskusi dan tukar pendapat juga mengalami peningkatan. Hal tersebut dibuktikan dari hasil observasi bahwa kegiatan di siklus II yaitu pada aspek motivasi dan kerjasama siswa mampu meningkat. Lebih dari $80 \%$ siswa juga telah antusias dan bersemangat serta kompak saat pembelajaran berlangsung.

\section{PEMBAHASAN}

Penggunaan metode role playing untuk meningkatkan hasil belajar siswa melalui tindakan atau siklus dapat dikatakan berhasil. Sebelum tindakan menggunakan metode pembelajaran role playing, nilai rata-rata siswa masih tergolong dibawah standard minimum. Siswa yang memiliki nilai kurang baik masih cukup banyak. Dari data tersebut, perlulah diadakan perlakuan untuk meningkatkan hasil belajar Bahasa Indonesia.

Penerapan siklus I yang sudah mulai berjalan memiliki peningkatan pada hasil test nya, dan kegiatan diskusi siswa. Namun hal tersebut masih kurang untuk mencapai target yang dibuat. Penyebab kurangnya keberhasilan pada siklus I mungkin dikarenakan kurang konsentrasi siswa dalam memainkan peran serta memahami isinya. Selain hal tersebut, guru mungkin kurang memotivasi belajar siswa sehingga perlulah diadakannya siklus II.

Dalam kegiatan penerapan siklus II, guru mengubah cara belajar siswa yakni dengan menambah gambar pada materi pembelajaran yang sedang berlangsung untuk mampu merangsang pemikiran yang baru sehingga siswa lebih fokus terhadap materi. Selain itu, guru juga memberikan reward bagi siswa yang mampu mengungkapkan pendapat dan aktif pada saat pembelajaran. Hal tersebut berhasil memotivasi siswa untuk mampu aktif dalam pembelajaran yang dilakukan dan meningkatkan kerjasama dalam diri siswa dalam berdiskusi.
Sebelum melaksanakan tindakan, tingkat ketercapaian hasil belajar siswa dalam pembelajaran Bahasa Indonesia hanya $60 \%$. Namun setelah diadakannya tindakan di siklus I, tingkat pencapaian siswa meningkat $10 \%$ dan kemudian dilanjut kembali di siklus II yang mengalami peningkatan $20 \%$ dari pra tindakan. Ketercapaian hasil tersebut karena dorongan dari guru dan kemampuan siswa melatih kembali memainkan peran, memahami isi, dan membacakannya dengan baik dan benar.

Dari data di atas pula, tingkat motivasi dan kerjasama siswa dalam mengungkapkan pendapat juga mengalami peningkatan. Pencapaian motivasi siswa dari siklus I ke siklus II mengalami peningkatan sebanyak $10 \%$. Sedangkan pencapaian kerjasama siswa dari siklus I ke siklus II mengalami peningkatan sebanyak $14 \%$.

Setelah penerapan siklus I dan siklus II untuk meningkatkan hasil belajar Bahasa Indonesia menggunakan metode pembelajaran role playing, berikut ini dijelaskan mengenai kelebihan dan kekurangan dari metode ini.

\section{Kelebihan Metode Role Playing}

1) Membuat pembelajaran lebih menyenangkan

Pembelajaran menggunakan metode role playing membuat siswa menjadi aktif karena dengan menggunakan metode role playing, siswa dapat berperan aktif di dalam pembelajaran sehingga siswa menjadi lebih tertarik terhadap proses pembelajaran sehingga pembelajaran menjadi lebih menyenangkan. Hal tersebut terbukti pada meningkatnya nilai dari respon siswa dari sebelum tindakan hingga pada siklus II.

Pada siklus I hampir semua siswa berpendapat dan melakukan diskusi dengan baik dan berperan aktif dalam pembelajaran. Dalam penilaian hasil belajar menunjukan hasil 70\% dari siswa 10 siswa mencapai kriteria ketuntasan minimal 70, dan menunjukan rata-rata motivasi belajar 
didalam kelas $75 \%$ dari 10 siswa, dan kerjasama menunjukan rata-rata $75 \%$ dari 10 siswa bekerja sama dengan baik.

Pada siklus II, hampir semua siswa menunjukan peningkatan hasil belajar yang sangat siknifikan yaitu. Dalam penilaian hasil belajar menunjukan hasil $80 \%$ dari siswa 10 siswa mencapai kriteria ketuntasan minimal 70, dan menunjukan rata-rata motivasi belajar didalam kelas $85 \%$ dari 10 siswa, dan kerjasama menunjukan rata-rata $90 \%$ dari 10 siswa bekerja sama dengan baik.

2) Menumbuhkan bakat dan potensi siswa

Dengan metode role playing ini akan menumbuhkan bakat dan potensi siswa karena siswa dilatih untuk memerankan suatu tokoh sesuai dengan karakter tokoh yang ada di dalam drama. Sehingga potensi siswa akan tergali karena terbiasa untuk memerankan tokoh, melatih keberanian siswa dalam mengungkapkan pendapat dan tampil di depan kelas.

3) Meningkatkan kerjasama antar siswa

Metode pembelajaran role playing ini jika diterapkan dalam pembelajaran sangat meningkatkan kerjasama antar siswa karena siswa dituntut untuk bekerja dalam kelompok, membagi tokoh-tokoh yang diperankan dalam drama, bekerjasama dalam memerankan drama di depan kelas, dan meningkatkan kekompakan siswa dalam kelompok serta melatih siswa untuk menghargai pendapat teman satu kelompok. Dengan adanya drama ini membuat siswa menjadi antusias dalam mengikuti pelajaran. Hal tersebut terbukti pada meningkatnya nilai dari kemampuan kerjasama siswa dari sebelum tindakan hingga pada siklus II.

\section{SIMPULAN}

Dari hasil penelitian yang telah dilaksanakan dapat disimpulkan sebagai berikut:

1. Penerapan metode role playing untuk meningkatkan hasil belajar siswa karena aktifitas siswa menyenangkan, menarik dan bermakna. Penggunaan metode ini dapat melatih keberanian siswa dalam mengungkapakan pendapatnya dan meningkatkan motivasi belajar siswa serta kerjasama siswa dalam berdiskusi. Interaksi siswa sangat tampak ketika proses mengomentari isi drama yang diperankan teman. Terlihat banyak siswa yang mampu memberikan kritik dan saran dari drama yang disampaikan dari kelompok lain. Penggunaan metode ini juga mendapat apresiasi yang baik. Siswa merasa tertarik dengan penggunaan metode dalam penyampaian materi dan siswa menantikan pembelajaran dengan mengunakan metode pembelajaran role playing.

2. Hasil belajar pelajaran Bahasa Indonesia dengan metode role playing.

a. Motivasi siswa mencapai indikator pencapaian motivasi dengan ketentuan mendapatkan nilai $\geq 75$ sebanyak $80 \%$ siswa.

b. Keterampilan kerjasama mencapai indikator pencapaian aspek kerjasama dengan ketentuan mendapatkan nilai $\geq 75$ sebanyak $80 \%$ siswa.

c. Hasil prestasi belajar mencapai indikator pencapaian aspek ketuntasan dengan ketentuan mendapatkan nilai $\geq 75$ sebanyak $80 \%$ siswa.

\section{PERSANTUNAN}

Peneliti mengucapkan terima kasih kepada berbagai pihak yang telah membantu dalam proses penelitian ini.

\section{DAFTAR PUSTAKA}

Abidin, Yunus. 2012. Pembelajaran Bahasa Berbasis Pendidikan Karakter. Bandung: PT Refika Aditama.

Kurniawan, Heru. 2015 Pemebelajaran Kreatif Kurikulum 2013. Jakarta: Prenada Group.

Pamungkas, Sri. 2012. Bahasa Indonesia dalam Berbagai Perspektif. Yogyakarta: Andi Offset. 
Saefuddin A., dan Berdiati, I. 2014.

Pembelajaran Efektif. Bandung:

Remaja Rosdakarya.

Uno, H.B. 2014. Model Pembelajaran

Menciptakan Proses Belajar

Mengajar yang Kreatif dan Efektif.

Jakarta: Bumi Aksara. 